Authors

M. Claudia tom Dieck, Ph.D.

Research Associate

Faculty of Business and Law,

Manchester Metropolitan University

Righton Building, Cavendish Street, Manchester M15 6BG, UK

Email: c.tom-dieck@mmu.ac.uk, Tel: +44 161-247-2729

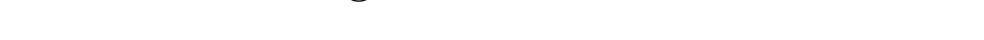

Timothy Jung, Ph.D.*

Reader

Faculty of Business and Law

Manchester Metropolitan University

Righton Building, Cavendish Street, Manchester M15 6BG, UK

Email: t.jung@mmu.ac.uk, Tel: +44 161-247-2701

Philipp A. Rauschnabel, Ph.D

Assistant Professor

\author{
15 November, 2017 \\ Exclusively Submitted to Computers in Human Behavior \\ *Corresponding author
}




\title{
Determining Visitor Engagement through Augmented Reality at Science Festivals: An
} Experience Economy Perspective

\begin{abstract}
Augmented reality (AR) has been increasingly implemented to enhance visitor experiences, and tourism research has long understood the importance of creating memorable experiences, leading to the research era of experience economy. Although technology-enhanced visitor engagement is crucial for science festivals, research focusing on visitor engagement through AR using the experience economy perspective is limited. Therefore, the aim of this study is to examine how the educational, esthetics, escapist and entertainment experience using AR affect visitor satisfaction and memorable experience, and eventually, lead to visitor engagement with science experiences in the context of science festivals. A total of 220 data inputs were collected as part of the European City of Science festivities and Manchester Science Festival 2016 and analyzed using structural equation modelling. Findings show that the four realms of experience economy influence satisfaction and memory and, ultimately, the intention for visitor engagement with science research at science festivals. Theoretical contributions and practical implications are presented and discussed.
\end{abstract}

Keywords: Augmented reality, science festivals, visitor engagement, experience economy, satisfaction, memory

\section{Introduction}

Festivals are considered one of the key activities that boost visitor economy, and many cities around the world use festivals to attract visitors. According to Bultitude et al. (2014), science festivals are particularly common within Europe and a driver for international and domestic tourism activities. Research has shown that achieving visitor engagement is critical for any festival in order to be successful and sustainable (Stilgoe et al., 2014). In particular, "science festivals have expanded in size and number over the recent years as a form of public engagement" and "public engagement has become the new mantra" in Europe (Jensen \& Buckley, 2014, p. 558). The main objectives of science festivals include the celebration of science and engaging of non-specialist audiences (Bultitude et al., 2014). Technology was found to be a solution in order to facilitate the engagement of visitors. One of the more recent technologies on the market is augmented reality (AR) which is the overlay of digital content into users' immediate surroundings, "allowing users to explore the surrounding environment by using mobile technologies" (Georgiou \& Kyza, 2017, p. 24). Benefits of AR in terms of visitor engagement, immersion, and education make it a promising technology to engage visitors in science as part of their visit to science festivals (Altimira et al., 2017; Georgiou \& Kyza, 2017). In fact, the main criticism of science festivals from the perspective of visitor engagement are 1) that they often neglect underrepresented audiences, and 2) that they preach to the already converted, as visitors are generally well-educated and interested in the themes (Bultitude, 2014). In order to overcome these potential issues in relation to engagement activities, technology-enhanced visitor engagement is considered as crucial, particularly for science festivals (Stilgoe et al., 2014). New and emerging digital technologies, such as AR, have been used for the enhancement of visitor experiences (Moorhouse et al., 2017). However, there is only limited research on technology-enhanced visitor engagement using $\mathrm{AR}$ in the context of science festivals. 
Recently, research started to use the framework of the Experience Economy by Pine and Gilmore (1998) as a theoretical foundation to explore the effects of AR (Jung et al., 2016; Neuburger \& Egger, 2017). It includes the four realms of experience, educational, esthetics, escapist and entertainment. This research direction is very valuable within the context of visitor economy considering the importance of enhancing the visitor experience through various forms of interaction in order to increase or sustain tourist numbers, enhance the level of engagement, and generate positive word-of-mouth to ensure future sustainability. Pine and Gilmore's Experience Economy model is considered to be the predominant framework within the subject area of visitor experiences (Jung et al., 2016). Rather than simply providing products and services, Pine and Gilmore (1998) emphasized the importance of staging experiences. Within the service-driven tourism domain, many scholars have supported the importance of tourist participation for the cocreation of value (Sorensen \& Jensen, 2015).

Although numerous scholars (e.g., Manthiou et al., 2014; Mehmetoglu and Engen, 2011; Oh et al., 2007) applied the Experience economy framework in other tourism and hospitality contexts, several limitations remain. First, prior research conceptualized the four dimensions as independent constructs or as a higher order constructs. In this study, we provide arguments for a process view. In particular, we argue that "the first impression matters" - that esthetics are the source of experience, resulting in an increase in educational, escapist and entertainment. Second, prior research has mostly applied experience economy to explain established constructs, such as loyalty (e.g. Manthiou et al.; 2014). This study complements prior research with a novel and managerially highly target construct: Visitor engagement. Finally, despite the general consensus that experience economy provides numerous advantages to media and tourism research, and scholars agree that science festivals are an important subject to study, empirical applications remain of experience economy remain scarce.

In order to achieve the aim of this study we proposed a theoretical model grounded in the experience economy literature. To test the model, a total of 220 data were collected as part of the European City of Science festivities and Manchester Science Festival 2016 and analyzed using structural equation modelling. The findings offer a number of contributions to the literature. On the one hand, findings show that esthetics is a strong predictor of escapism, education, and entertainment within the AR science festival context. Therefore, this study shows that the experience economy concept in the context of AR applications does not consist of four independent dimensions. On the other hand, this study found that the remaining three realms of the experience economy influence visitors' satisfaction and memories of the AR science festival experience which ultimately influences visitors' engagement.

\section{Theoretical Background}

2.1 Augmented Reality and Visitor Experience

AR is the digital overlay of information into users' direct surroundings using devices such as smartphones or wearable smart glasses (Jung et al., 2015; Kalantari \& Rauschnabel, 2017; Tussyadiah et al., 2017). AR is a source of technological innovation (Neuhofer et al., 2012); if implemented correctly, destinations can effectively obtain a competitive advantage and attract new markets (Tscheu and Buhalis, 2016). The creation of mobile AR is especially considered to be attractive, as visitors can use applications on their smartphones, reducing the barrier to engage and 
adopt (Han et al., 2014; tom Dieck and Jung, 2015). For example, visitors can hold their smartphone with an AR app against a building and receive relevant information. Likewise, visitors of museums can look at exhibits through an AR app and learn more about them. These two example applications reflect conclusions of prior research that this cutting-edge technology can enhance and add value to the overall visitor experience, provide a motivation to visit, and generate positive word-of-mouth (Morrison, 2013). At attractions, visitors can instantly access and unlock historic knowledge and reveal hidden stories, whilst avoiding interrupting or overcrowding the physical space (Molz, 2012). This effectively bridges the gap between exploring innovative technologies and personalized experiences, as visitors can tailor the experience and explore and discover personal points of interest (Neuhofer et al., 2015). In addition, the overlay of 2D and 3D graphics engages the user ( $\mathrm{Wu}$ et al., 2013) and encourages new and innovative ways of learning (Moorhouse et al., 2017). Overall, AR can enhance the attractiveness of destinations when marketed effectively by destination management organisations (Tscheu and Buhalis, 2016), as it can create a unique and memorable experience for visitors (Jung and tom Dieck, 2017). Nevertheless, according to Rauschnabel et al. (2017), AR acceptance remains a challenge and is under-researched, and must be overcome by lower complexities in the design and implementation process (Wu et al., 2013).

\subsection{Experience Economy}

To understand AR, researchers have applied numerous theories in different study contexts. Studies with a focus on the device itself have applied technology acceptance theories (e.g. Rauschnabel \& Ro, 2016). In contrast, other research has highlighted a theoretical framework termed 'experience economy' (Pine \& Gilmore, 1998). Research has long understood the importance of creating memorable experiences (Kang \& Gretzel, 2012; Park et al., 2010; Quan \& Wang, 2004) and, therefore, the move from the service economy to the experience economy comes as no surprise 160 (Knutson et al., 2010).

The initial idea of the experience economy proposed four realms of consumer experiences based on two dimensions: involvement, ranging from passive to active participation of the consumer, and the desire, ranging from absorption to immersion, within which a consumer engages with a consumption object. The experience economy suggests that there are four realms of an experience, as displayed in Figure 1, which can be classified by a spectrum of connection (immersion and absorption) along the vertical, and a spectrum of participation (active and passive)) along the horizontal line of the model (Pine \& Gilmore, 1998). According to Quadri-Felitti and Fiore (2013, p. 48), "active participation is where customers personally affect the performance or event, and passive participation is where customers do not directly affect or influence the performance. In addition, immersion is described as becoming physically or virtually enveloped by the event [...] whereas absorption involves engaging the consumer's mind". 


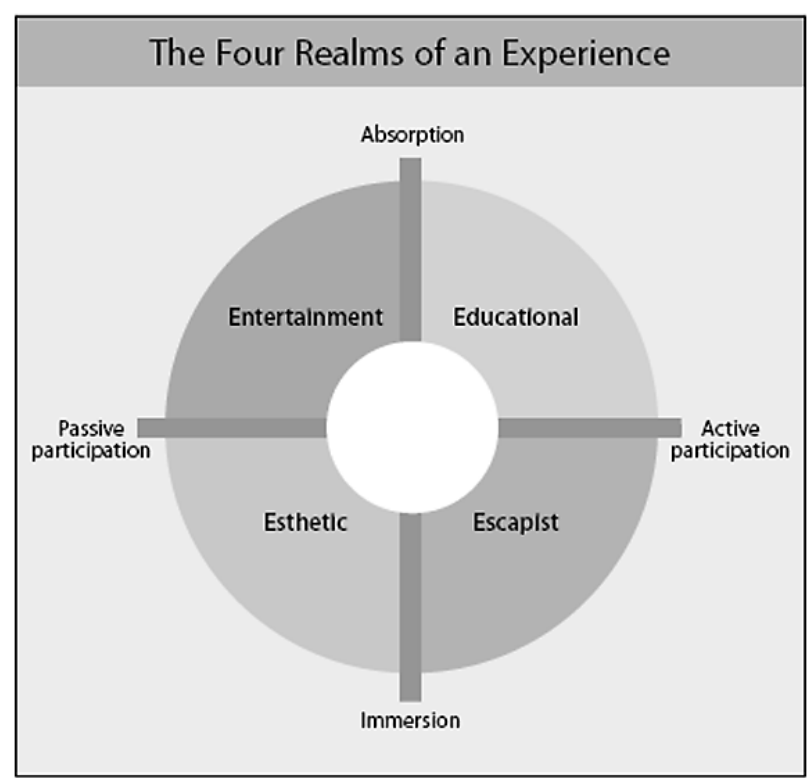

Fig. 1. Experience Economy (Pine \& Gilmore, 1998)

Within the educational realm, visitors are actively engaged in tourism activities to gain new skills and knowledge (Oh et al., 2007). A number of previous studies have confirmed the role of AR as an effective tool for education, supporting its strength in creating interactive content that is easy to remember (e.g. Moorhouse et al., 2017; tom Dieck et al., 2016). As part of the entertainment experience, Jung et al. (2016) proposed that users utilize applications for an enjoyable experience. Based on the Experience Economy model, this enjoyable and entertaining experience is in the form of a more passive delivery of content (e.g. movies). Escapism is the third realm of experience and refers to visitors' active participation in the delivery of products and services as well as visitors' willingness to momentarily forget happenings within their normal lives by fully immersing in the experience (Song et al., 2015). Finally, esthetics were originally proposed to reflect visitors' full immersion within an experience that does not interact with them (Pine \& Gilmore, 1998). Considering the importance of immersion as part of an AR experience, Jung et al. (2016) argued that escapism and esthetics become increasingly more important with the emergence of AR applications. Scholars from various disciplines have adopted the idea and applied it to numerous contexts (see Table 1).

\begin{tabular}{llllll}
\hline Study & Research Question/Aim & Context & $\begin{array}{l}\text { Sample and } \\
\text { Methods }\end{array}$ & $\begin{array}{l}\text { Conceptualization } \\
\text { of Experience } \\
\text { Economy }\end{array}$ & $\begin{array}{l}\text { Findings relevant to the study } \\
\text { context / this study's } \\
\text { contribution }\end{array}$ \\
\hline $\begin{array}{l}\text { Hosany \& } \\
\text { Witham }\end{array}$ & $\begin{array}{l}\text { Development of a } \\
\text { measurement scale for } \\
\text { tourist experience }\end{array}$ & $\begin{array}{l}\text { Cruise } \\
\text { Tourism }\end{array}$ & $\begin{array}{l}\mathrm{N}=169, \\
\text { Confirmatory } \\
\text { factor } \\
\text { analysis and } \\
\text { regression } \\
\text { analysis }\end{array}$ & On one level & $\begin{array}{l}\text { The study provides a } \\
\text { measurement scale for the } \\
\text { experience economy } \\
\text { dimension. Results generally } \\
\text { reveal homological validity }\end{array}$ \\
$\begin{array}{l}\text { Jung et al. } \\
(2016)\end{array}$ & $\begin{array}{l}\text { Explore if experience could } \\
\text { be enhanced by social } \\
\text { presence in the mixed } \\
\text { reality environment and } \\
\text { further inducing revisit } \\
\text { intention to visitor } \\
\text { attraction }\end{array}$ & $\begin{array}{l}\text { AR and } \\
\text { VR in }\end{array}$ & Museums & On one level & Social presence impact \\
& & & & $\begin{array}{l}\text { Sexperience economy } \\
\text { constructs } \\
\text { Only Education and } \\
\text { Entertainment drive the } \\
\text { overall tour experience }\end{array}$
\end{tabular}




\begin{tabular}{|c|c|c|c|c|c|}
\hline $\begin{array}{l}\text { Loureiro } \\
(2014)\end{array}$ & $\begin{array}{l}\text { Explore } \\
\text { the } \\
\text { effect } \\
\text { of } \\
\text { Experience economy on } \\
\text { place } \\
\text { attachment } \\
\text { and } \\
\text { intention }\end{array}$ & $\begin{array}{l}\text { Rural } \\
\text { tourism }\end{array}$ & $\mathrm{N}=222 ., \mathrm{PLS}$ & $\begin{array}{l}\text { Higher order } \\
\text { construct }\end{array}$ & $\begin{array}{l}\text { The correlation matrix } \\
\text { suggests that the strength of } \\
\text { the experiences differ } \\
\text { between target constructs, } \\
\text { indicating that each } \\
\text { dimension behaves } \\
\text { differently in the context. }\end{array}$ \\
\hline $\begin{array}{l}\text { Manthiou et } \\
\text { al. }(2014)\end{array}$ & $\begin{array}{l}\text { Explore visitor experiences } \\
\text { to understand future } \\
\text { behaviour }\end{array}$ & $\begin{array}{l}\text { Festival } \\
\text { Marketing }\end{array}$ & $\mathrm{N}=338, \mathrm{SEM}$ & On one level & $\begin{array}{l}\text { Four experience realms result } \\
\text { in an optimal experience, } \\
\text { influencing vividity as a } \\
\text { mediating and loyalty as a } \\
\text { dependent variable. }\end{array}$ \\
\hline $\begin{array}{l}\text { Mehmetoglu } \\
\text { \& Engen } \\
(2011)\end{array}$ & $\begin{array}{l}\text { Explore how different } \\
\text { experiential dimensions } \\
\text { influence satisfaction }\end{array}$ & $\begin{array}{l}\text { Museum } \\
\text { and } \\
\text { Festival }\end{array}$ & $\begin{array}{l}\mathrm{N}=75 \text { and } \\
\mathrm{N}=117, \mathrm{PLS} \\
\mathrm{SEM}\end{array}$ & On one level & $\begin{array}{l}\text { Mixed findings depending on } \\
\text { the context and target } \\
\text { variable }\end{array}$ \\
\hline $\begin{array}{l}\text { Oh et al. } \\
(2007)\end{array}$ & $\begin{array}{l}\text { Development of a scale and } \\
\text { assessing its nomological } \\
\text { validity }\end{array}$ & $\begin{array}{l}\text { Hotel } \\
\text { industry }\end{array}$ & $\begin{array}{l}\mathrm{N}=419, \mathrm{CFA} \\
\text { and } \\
\text { correlation }\end{array}$ & On one level & $\begin{array}{l}\text { Measurement scale that is } \\
\text { correlated with Arousal, } \\
\text { Memory, Quality, and } \\
\text { Satisfaction; no regression- } \\
\text { based results are presented. }\end{array}$ \\
\hline This study & $\begin{array}{l}\text { Explore the effect of AR } \\
\text { experience influence on } \\
\text { visitors' engagement with } \\
\text { science experience }\end{array}$ & $\begin{array}{l}\text { AR for } \\
\text { science } \\
\text { festivals }\end{array}$ & $\begin{array}{l}\mathrm{N}=220, \\
\mathrm{SEM}\end{array}$ & $\begin{array}{l}\text { Mediating } \\
\text { structure, where } \\
\text { esthetics drive } \\
\text { entertainment, } \\
\text { education and } \\
\text { escape, which the } \\
\text { subsequently } \\
\text { impact outcome } \\
\text { variables }\end{array}$ & $\begin{array}{l}\text { We show that experience } \\
\text { economy constructs are not } \\
\text { independent from each other, } \\
\text { but represent a networked } \\
\text { structure. } \\
\text { Experience economy } \\
\text { constructs play an important } \\
\text { role in explaining visitors' } \\
\text { reactions on AR apps }\end{array}$ \\
\hline
\end{tabular}

Table 1. Summary of previous studies

While the flexibility is a major strength of the experience economy framework, it is also associated with a number of concerns, ranging from criticism on the conceptualization to lack of measurement challenges. While addressing the measurement challenges of each of the four experiences have been subject to numerous studies (e.g. Oh et al., 2007; Hosany \& Witham, 2009), the overall conceptualization provides some unanswered questions. For example, whereas Pine and Gilmore (1998) argued that the interaction of two dimensions, involvement and desire, are sufficient to generate four types of experience, other studies, especially in the tourism context, have found that each of the four experiences should either serve as individual dimensions, or be treated as a higherorder construct (e.g. Loureiro, 2014). However, as shown in Table 1, studies that compared the effects of each of the four constructs on target variables often concluded that only a few of them matter. An inspection of the correlations between the factors indicates meaningful correlations between all four variables, indicating that - contrary to Pine and Gilmore (1998)'s framework the four constructs are not independent of each other. This study aims to extend prior research on experience economy in several ways.

As presented in Table 1, the majority of studies (Hosany \& Witham, 2016; Jung et al., 2016; 211 Mehmetoglu \& Engen, 2011; Oh et al., 2007) tested the experience economy constructs on one 212 level and supported the effects of all or some of the four constructs on the experience within 213 various tourism-related contexts. For instance, Jung et al. (2016) failed to find a significant relation 214 of esthetics onto the overall experience, raising the question of the appropriateness of seeing or 
applying each construct on one level. In addition, none of the studies incorporated the effects of

Thus, the aim of this study is to address this gap in the literature as follows. First, this study aims to apply the experience economy framework to investigate factors relating to visitor engagement in the context of science festivals. Second, this research assesses the mediation effects of memory and satisfaction in the experience economy - engagement relationship. Finally, this study proposes a novel view on the interplay of the experience economy constructs. Rather than stating that each of the four realms is independent from each other or that all together reflect a higher order construct, we propose a mediating structure.

\section{Proposed Model}

Figure 2 shows the basic theoretical framework of this study. First, we propose that visitors' actual use of an AR device triggers the constructs of the experience economy framework, whereas - in contrast to prior research (see Table 1) - we provide a more nuanced relationship between the four constructs. Second, we propose that experience economy constructs determine visitors' overall evaluation of the on-site AR experience. In particular, we propose that the experience economy serves how much people enjoyed using the AR experience (satisfaction), but also to what extend the experience stays in their mind (memory). Third, the model proposes that satisfaction and memory both impact visitor engagement, a crucial, yet under-researched, construct in tourism research.

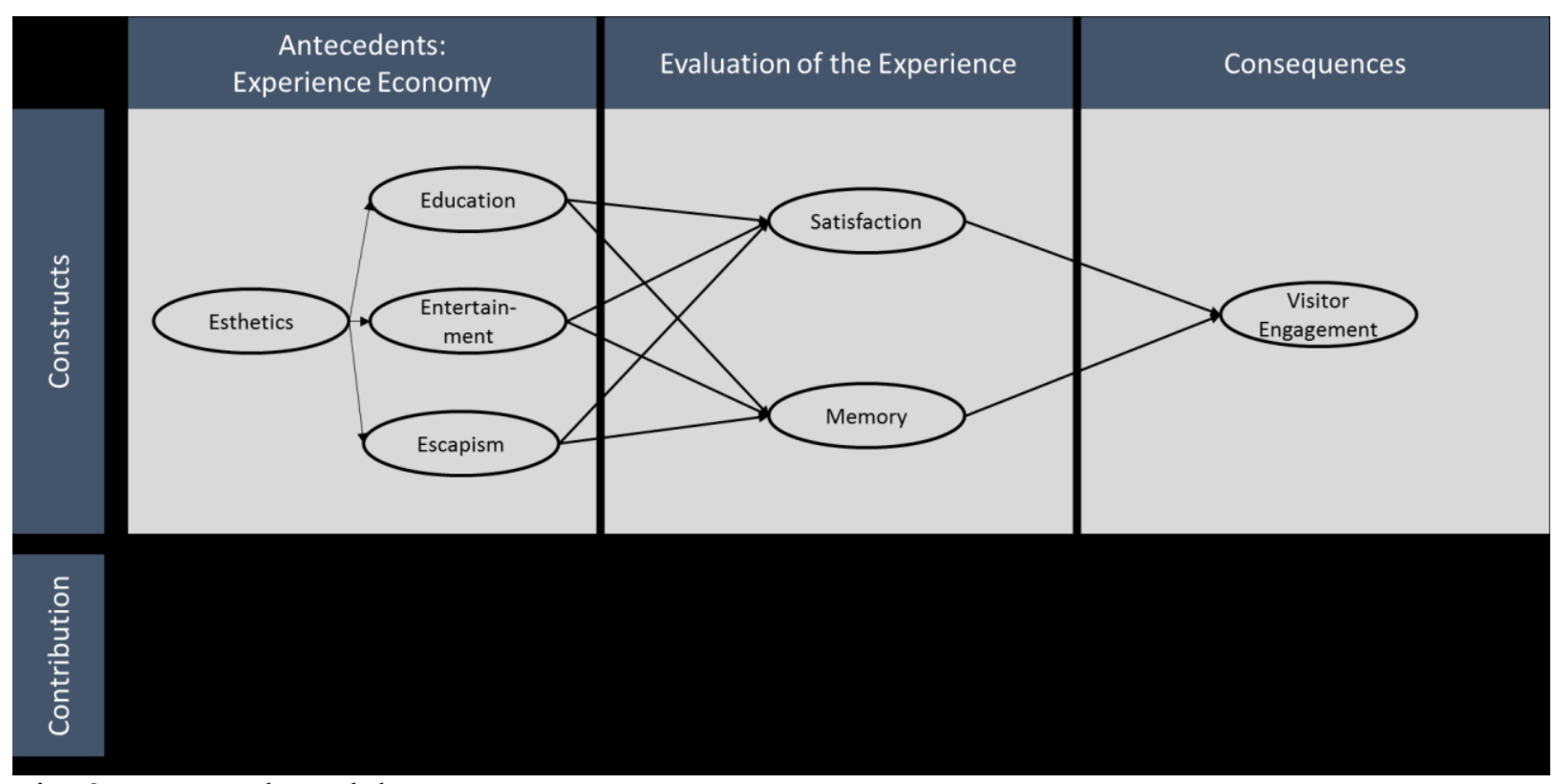

Fig. 2. Proposed Model

\subsection{Experience Economy}

Research in numerous domains has shown that visible cues are the first cues that people use to make judgments about people and things. For example, when interacting with other people, physical cues (e.g. face, cloths etc.) are among the first cues people use to judge a persona, such as sympathetic, smart, etc. Similarly, when using a new software, one of the first users incorporate 
into their decision making is the design of the user interface. We argue that this general finding is also relevant in the creating of visitor experience.

248 In a related context, Pallud and Straub (2014) show that aesthetics represent the most important criteria for interface development, which ultimately dictates whether visitors accept or reject latest technologies. In particular, especially when technologies become more immersive, both Jung et al (2016) and Lee et al. (2015) argue that interface design becomes even more relevant than in less immersive contexts. Tourism scholars, such as Hosany and Witham (2009) or Mykletun \& Rumba (2014) even argue that esthetics are among the most important drivers within the experience economy. Likewise, Jung et al. (2018)'s cross-cultural study on AR concludes that esthetics are particularly relevant since it can compensate for technological limitations of many current AR devices. Consequently, this means that if esthetics of an experience are low, the educational, entertainment, and escapism experiences are likely to suffer. On the other hand, once users are exposed to a favourable esthetics experience, this should translate to higher levels of education (H1a), entertainment (H1b) and escapism (H1c) dimension. This is a different conceptualization of most prior studies (see table 1). In particular, most prior studies implicitly assume, for example, that users rate the escapism value of apps independently of their estethic experience. Simplified speaking, this would imply that the escapism experience would not suffer if an app was poorly designed (Jung et al., 2018). This assumption would also imply that poorly designed apps provide the same educational and entertainment experience than well-designed ones, assumptions that prior theory and reported correlations might question. Thus, we propose esthetics as a determinant of the remaining three experience constructs and, thus, the following is hypothesized:

H1a: Esthetics has a positive effect on education.

H1b: Esthetics has a positive effect on entertainment.

H1c: Esthetics has a positive effect on escapism.

\subsection{Experience Economy and Satisfaction}

According to Srivastava and Kaul (2014, p. 1028), satisfaction can be defined as "consumer judgment that a product or service provides a pleasurable level consumption-related fulfilment", which has long been discussed as an important determinant of behavioral intentions within technology adoption research (e.g. tom Dieck et al., 2017). According to Mehmetoglu and Engen (2011), experiences allow people to draw upon the events to paint a picture of their lives. They allow for an evaluation of an individual's perception of his or her self-image, which is the aggregation of his or her lifetime experiences. Following this logic, Mehmetoglu and Engen (2011) argued that individual experiences are highly important for consumers' views and satisfaction of products or services. Furthermore, as part of the experience economy, there has been sufficient evidence of strong impacts of the realms of experience economy on satisfaction. For instance, the effect of education and entertainment onto tourist satisfaction within the film festival context was supported by Park et al. (2010), and Quadri-Felitti and Fiore (2013) confirmed that education strongly affects satisfaction within the tourism context. Consequently, this study proposed that:

H2a: Education has a positive effect on satisfaction.

$\mathrm{H} 2 \mathrm{~b}$ : Entertainment has a positive effect on satisfaction.

$\mathrm{H} 2 \mathrm{c}$ : Escapism has a positive effect on satisfaction.

\subsection{Experience Economy and Memory}


Studies have long acknowledged the importance of experiencing events and the consequent creation of memories (Pine \& Gilmore, 1998). In fact, das Gupta et al. (2016, p. 1278) revealed "for many consumer-intensive (B2C) services, delivering memorable customer experiences is a source of competitive advantage". According to Manthiou et al. (2014), an experience involves the input of information into the sensory system of an individual's brain. Consequently, a memory is what remains of an event after the sensory experience occurred, making it an integral part of any experience framework.

In the context of the experience economy, it is, therefore, proposed that the experiences is considered the cause, and the memory is considered the effect (Manthiou et al., 2014). This was confirmed by Pine and Gilmore (1998), who revealed that an optimal experience should lead to enhanced memories. Kahneman (2011, p. 388) strengthened that "tourism is about helping people construct stories and collect memories". This was supported by Ali et al. (2014), who found that tourists' experiences revolving around the four realms of the experience economy result in strong memories and positive behaviors. Similar findings were determined in other tourism contexts, as Loureiro (2014) as well as Quadri-Felitti and Fiore (2013) tested the effect of experience economy onto memory within the festival and wine tourism context, and found that the educational experience significantly influenced memory. Entertainment was found to significantly influence memory by Mykletun and Rumba (2014). Therefore, it is proposed that:

H3a: Education has a positive effect on memory.

$\mathrm{H} 3 \mathrm{~b}$ : Entertainment has a positive effect on memory.

H3c: Escapism has a positive effect on memory.

\subsection{Satisfaction, Memory, and Visitor Engagement}

It has been well-recognized that satisfaction and positive memories influence behavioral intentions within technology adoption literature (Wixom \& Todd, 2005), particularly within the tourism context (Ali et al., 2014; Ali et al., 2016; Hosany \& Witham, 2009; tom Dieck et al., 2017). However, the direct comparison of these two crucial concepts, as well as their interaction, remains an under-researched area. As we propose and empirically validate, maximising both concepts might - counterintuitively - not be a desired strategy for tourism managers. There are several ways to measure behavioral intention within the technology adoption research stream. A number of studies have focused on the intention to use technology that is relatively new on the market (Rauschnabel \& Ro, 2016), continued usage intentions (tom Dieck et al., 2017), intention to recommend (Prayag et al., 2017) or loyalty (Valle et al., 2006). However, studies focusing on the intention for visitor engagement is scarce, and the overall area is highly under-researched. Nevertheless, as previously discussed, visitor engagement with particular themes within a destination can be considered extremely valuable in order to provide a unique, educational, and memorable visitor experience. Thus, we propose:

H4: Satisfaction has a positive effect on visitor engagement.

H5: Memory has a positive effect on visitor engagement.

4. Methods

4.1 Study context 
The study was conducted as part of the European City of Science (ECOS) festivities and Manchester Science Festival in Manchester, UK, in 2016. Among other ECOS initiatives, a mobile AR application (see Fig. 3) was developed in order to provide visitors to Manchester with an enhanced experience. In particular, the app provided information on ECOS events and the history of science in Manchester. Furthermore, one of the functionalities of the application was related to AR. iBeacons were located around the city centre, and whenever a visitor walked near a beacon, the app notified him about the opportunity to learn something new about Manchester science when scanning a certain object. These objects varied from statues to buildings or simply plaques. Once a visitor located and scanned such an object, information in form of audio, video, animation (see Fig. 4 Pokémon animation of scientist Prof. Brian Cox), or text were overlaid into visitors' immediate surroundings, representing the AR element of the application.

\subsection{Data Collection}

Questionnaires were collected as part of the ECOS festivities and Manchester Science Festival between July and December 2016. Data were collected from visitors who experienced the mobilebased AR application in the city centre of Manchester as part of their visit to the city. It is important to note that these tourists did not actively attend the science festival, but were visiting Manchester during the period. Random sampling was used and a total of 220 usable data inputs were collected. Shenton (2004) revealed that a random sampling technique increased the representativeness of a sample, as it includes the opinion of a general population rather than a selected sample. The researchers approached every $10^{\text {th }}$ visitor as part of the random sampling technique in front of the Central Library, one of the major squares of the city and a focal visitor point for tourists coming to Manchester. Prior to participation, participants were asked if they were tourists in Manchester, and only those confirming were selected. The study was designed as a science tour and prior to filling in questionnaires, tourists were asked to experience four different sites, including buildings, monuments, or statues in close proximity that provided AR content, triggered by iBeacons. The average tour lasted approximately 30 minutes. Participants were provided with Android phones and a map that showed AR-enabled sites by the researcher in order to ensure that every participant 


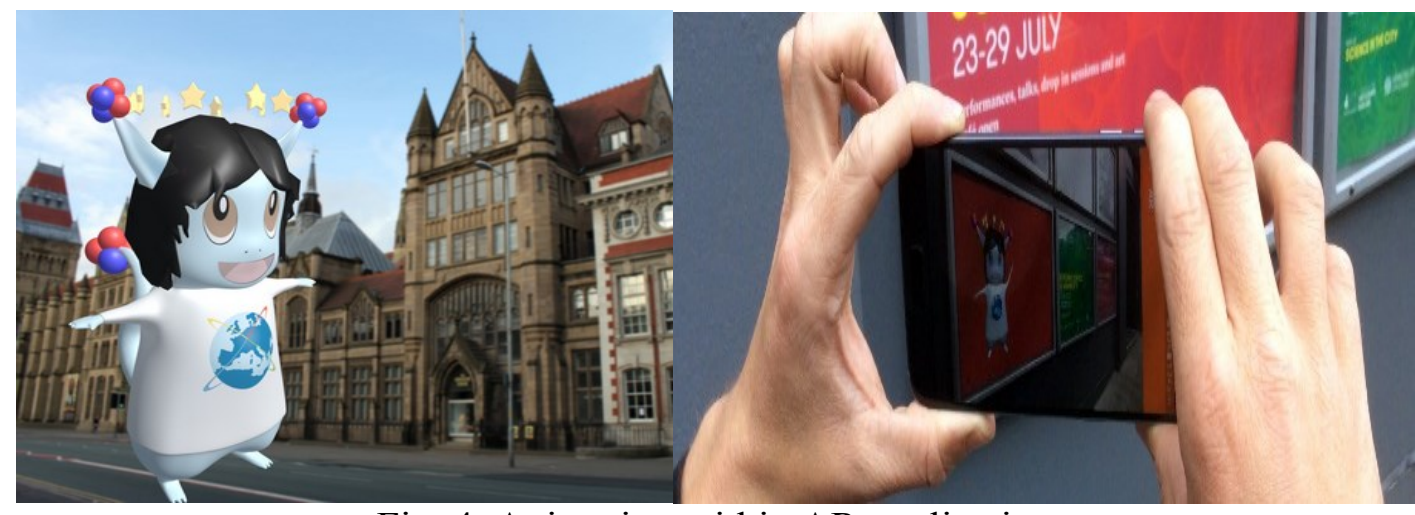

Fig. 4. Animation within AR application

5. Results

5.1 Profile of Participants

Participants' profiles are shown in Table 2 . There were slightly more males $(56.4 \%)$ than females (43.6\%). The majority of respondents was aged between 18 and 24. Almost half of participants had an undergraduate degree $(45.5 \%)$, followed by postgraduate degree $(27.7 \%)$ and A-levels (16.4\%). With regards to income level, less than $£ 20,000$ was mostly represented (51.8\%), and more than half or respondents were students $(57.3 \%)$.

\begin{tabular}{|c|c|c|c|c|c|c|}
\hline Characteristics & $\mathbf{N}$ & $\%$ & Characteristics & & $\mathbf{N}$ & $\%$ \\
\hline Gender & & & Income & & & \\
\hline Male & 124 & 56.4 & Less than $£ 20,000$ & & 114 & 51.8 \\
\hline Female & 96 & 43.6 & $£ 20,000-£ 40,000$ & & 66 & 30.0 \\
\hline Age & & & $£ 40,000-£ 60,000$ & & 24 & 10.9 \\
\hline $18-24$ & 128 & 58.2 & $£ 60,000-£ 80,000$ & & 9 & 4.1 \\
\hline $25-34$ & 54 & 24.5 & $£ 80,000-£ 100,000$ & & 0 & 0.0 \\
\hline $35-44$ & 16 & 7.3 & $£ 100,000+$ & & 7 & 3.2 \\
\hline $45-54$ & 15 & 6.8 & Occupation & & & \\
\hline $55-64$ & 4 & 1.8 & Full-time employed & & 74 & 33.6 \\
\hline $65+$ & 3 & 1.4 & Part-time employed & & 15 & 6.8 \\
\hline Education & & & Self-employed & & 3 & 1.4 \\
\hline No Formal Qualification & 4 & 1.8 & Housewife/husband & & 0 & 0.0 \\
\hline GCSE/O-level & 4 & 1.8 & Unemployed & & 2 & 0.9 \\
\hline A-level & 36 & 16.4 & Retired & & 0 & 0.0 \\
\hline Undergraduate Degree & 100 & 45.5 & Student & & 126 & 57.3 \\
\hline Postgraduate Degree & 61 & 27.7 & & & & \\
\hline Doctoral Degree & 13 & 5.9 & & & & \\
\hline Professional Degree & 2 & 0.9 & & Total & 220 & $100 \%$ \\
\hline
\end{tabular}

\section{Table 2. Participants Profile}

\subsection{Measures}

All constructs (see appendix for definitions) were measured by three to four measurement items and ranked on a Likert scale ranging from 1 (strongly disagree) to 5 (strongly agree). The measurement items were adapted from established reflective multi-item construct scales from previous literature (Loureiro, 2014; Manthiou et al., 2014; Mehmetoglu \& Engen, 2011; Oh et al., 2007; Quadri-Felitti \& Fiore, 2013). We inspected the psychometric characteristics of the measurement instrument using a series of exploratory and confirmatory factor analysis. Although 
the $\chi^{2}$-value of $350.2(\mathrm{df}=209)$ was significant $(\mathrm{p}<.001)$, the $\chi^{2} / \mathrm{df}$ ratio of 1.7 was lower than 4 and, thus, acceptable. In addition, the model fit (CFI=.95; TLI=.94; RMSEA=.06; SRMR=.05) reflects absence of substantial approximation errors and shows no substantial differences between observed and predicted correlation matrices. Then, we, assessed the psychometric characteristics on a construct level. As shown in Table 3, all factor loadings are significant $(\mathrm{p}<.001)$ and above .70 . In addition, Cronbach's alpha ( $\boldsymbol{\alpha})$, Composite Reliability (CR), and Average Variance Extracted 398 (AVE) exceeded the recommended threshold of .7, .7, and .5, respectively. We assessed 399 discriminant validity using the Fornell and Larcker (1981) procedure. Evidence of discriminant 400 validity exists in the study, as AVE values all are above the squared construct correlations (Hair 401 et al., 2006) (see Table 4).

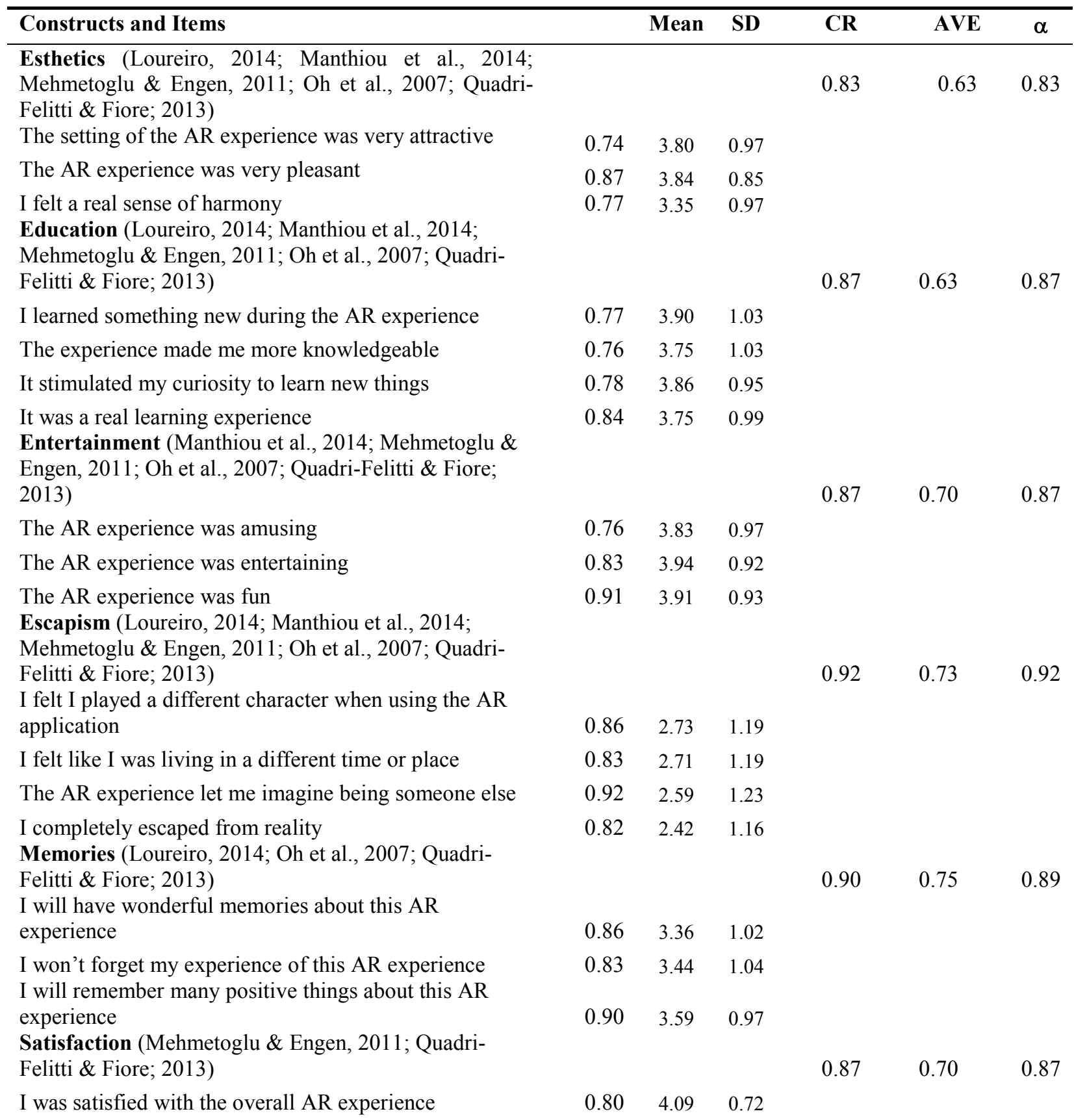


I was contented with the overall AR experience

I was delighted with the overall AR experience

Visitor Engagement (Criado \& Such, 2011; Isiaq \&

Jamil, 2017)

This experience has motivated me to find out more

about the history of science in Manchester

This experience has motivated me to find out more

about science research in Manchester

This experience has motivated me to participate in

science festival activities in Manchester

$\begin{array}{lll}0.86 & 3.82 & 0.78 \\ 0.85 & 3.82 & 0.81\end{array}$

0.86

0.68

0.86 $\begin{array}{lll}0.83 & 3.51 \quad 1.04\end{array}$

$\begin{array}{lll}0.87 & 3.51 \quad 1.06\end{array}$

$\begin{array}{lll}0.76 & 3.35 & 1.12\end{array}$

Table 3. Reliability and Cross-Loadings

\begin{tabular}{|c|c|c|c|c|c|c|c|}
\hline & & 1 & 2 & 3 & 4 & 5 & 6 \\
\hline 1 & Esthetics & & & & & & \\
\hline 2 & Education & 0.67 & & & & & \\
\hline 3 & Entertainment & 0.71 & 0.61 & & & & \\
\hline 4 & Escapism & 0.60 & 0.36 & 0.40 & & & \\
\hline 5 & Memory & 0.60 & 0.54 & 0.49 & 0.42 & & \\
\hline 6 & Satisfaction & 0.61 & 0.63 & 0.60 & 0.37 & 0.56 & \\
\hline 7 & Visitor Engagement & 0.55 & 0.53 & 0.42 & 0.36 & 0.45 & 0.58 \\
\hline
\end{tabular}

404

405

406

407

408

409

410

411

412

413

414

415

416

417

418

419

420

correlations are significant at $\mathrm{p}<.00$

Table 4. Correlation and discriminant validity

\subsection{Main Effects}

Mplus 7.1 (Muthen \& Muthen, 2012) was used to model the structural relationships proposed in the hypotheses (see Figure 5). We applied the MLR estimator to estimate the model, a maximum likelihood estimator with a robust error term. In survey research, common assumptions for maximum likelihood estimators, such as multivariate Gaussian distribution or sample size, are not given. Recent research shows that MLR outperforms traditional ML-estimators in these realistic scenarios. Global fit measures of this main effects model indicate a good model fit $(\chi 2=369.7$; $\mathrm{df}=218 ; \mathrm{CFI}=.95 ; \mathrm{TLI}=.94 ; \mathrm{RMSEA}=.056 ; \mathrm{SRMR}=.058)$.

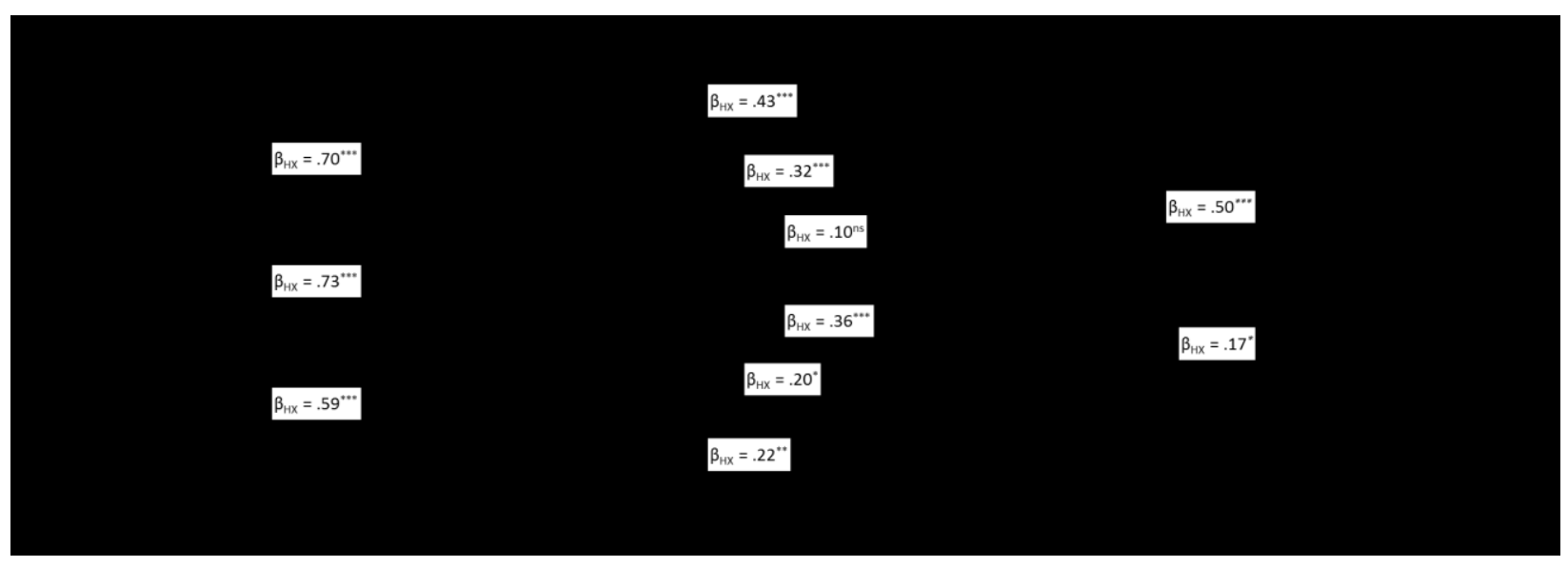

Fig. 5. Structural Equation Model 
Results indicate significant effects from esthetics on education $\left(\beta_{\mathrm{H} 1 \mathrm{a}}=.70 ; \mathrm{p}<.001\right)$, entertainment $\left(\beta_{\mathrm{H} 1 \mathrm{~b}}=.73 ; \mathrm{p}<.001\right)$, and escapism $\left(\beta_{\mathrm{H} 1 \mathrm{c}}=.59 ; \mathrm{p}<.001\right)$. Thus, results support H1a, H1b, and H1c. Next, we investigate the effects from the three endogenous experience economy variables on satisfaction and memory. Results show significant effects for education $\left(\beta_{\mathrm{H} 2 \mathrm{a}}=.42 ; \mathrm{p}<.001\right)$ and entertainment $\left(\beta_{\mathrm{H} 2 \mathrm{~b}}=.32 ; \mathrm{p}<.001\right)$ on satisfaction, supporting $\mathrm{H} 2 \mathrm{a}$ and $\mathrm{H} 2 \mathrm{~b}$. Results for escapism are in the proposed direction, $\left(\beta_{\mathrm{H} 2 \mathrm{c}}=.10 ; \mathrm{p}=.14\right)$, but do not reach significance, rejecting $\mathrm{H} 2 \mathrm{c}$. These variables together explain $49.4 \%$ of satisfaction's variance. Memory, in contrast, is influenced by education $\left(\beta_{\mathrm{H} 3 \mathrm{a}}=.36 ; \mathrm{p}<.001\right)$, entertainment $\left(\beta_{\mathrm{H} 3 \mathrm{~b}}=.20 ; \mathrm{p}=.02\right)$, and escapism $\left(\beta_{\mathrm{H} 3 \mathrm{c}}=.22 ; \mathrm{p}<.01\right)$ supporting H3a, H3b, and H3c. These variables together explain $38.7 \%$ of memory's variance. Finally, we inspect the constructs that are hypothesized to relate to public engagement. In support of $\mathrm{H} 4$ and $\mathrm{H} 5$, results show significant effects for satisfaction $\left(\beta_{\mathrm{H} 4}=.50 ; \mathrm{p}<.001\right)$ and a partially effect for memory $\left(\beta_{\mathrm{H} 5}=.17 ; \mathrm{p}=.06\right)$. Both constructs explain $37.7 \%$ in consumers variation regarding public engagement. Following recent recommendations in mediation research, we also assessed the indirect effects. Therefore, we ran 10,000 bootstrap resamples and estimated the $95 \%$ confidence intervals. A mediation effect is established if its confidence interval an indirect effect does not include zero. Mediation was established for all indirect effects, except the esthetics $\rightarrow$ escapism $\rightarrow$ satisfaction link, where also H2c did not receive empirical support. Details are presented in Appendix 2.

\section{Discussion, Implications, and Limitations}

The aim of this study was to examine how visitor experience using AR affect visitors' satisfaction, memory, and eventually visitors' engagement with science experience in the context of science festivals. The results showed that esthetics are a strong predictor of education, entertainment, and escapism within the AR experience in the science festival context. Consequently, it can be argued that AR experience design and the harmonious integration of content and features is critical in order to provide visitors with an educational, enjoyable, and escaping experience. Theoretically, this study shows that the experience economy in the context of AR applications and science festivals does not consist of four independent dimensions. In comparison to previous studies (e.g. Jung et al., 2016; Manthiou et al., 2014) that tested the experience dimensions on one-level (as presented in Table 1) and, thereby, often failed to find all four experience dimensions significant, the present study supported all four dimensions using a mediating structure. In fact, this study has shown that esthetical design of the application drives the remaining experience economy constructs, which is supported by previous research on the importance of AR user requirements in terms of application design (tom Dieck et al., 2016).

In addition, this study supports that the remaining three realms of the experience economy influence visitors' satisfaction and positive memories of the AR science festival experience. This ultimately influences visitors' engagement with science. Considering the importance for cities to engage visitors with their heritage, the use of AR was found to not only bring history to life, but also actively engages visitors and facilitates the gathering of new information. This is especially important considering that science festivals aim to engage a broader audience, and AR can be used in order create awareness and public engagement among so far neglected audiences (Bultitude, 2014). For the visitors industry, AR provides an opportunity to create awareness of points of interests that cities and destinations have to offer. In the future, applications do not need to be limited to a science or history tour, but destinations could offer personalized tours to tourists based 
on their interests and preferences. This shows the clear potential for destinations to utilize AR to create unique selling points and memorable experiences, a key aim of Pine and Gilmore's (1998) framework.

\subsection{Theoretical Contributions}

This study has several theoretical contributions. The most important contributions are (1) a novel conceptualization of experience economy, and (2) the identification of two routes how satisfaction and memory compete in driving a third crucial variable in AR research: visitor engagement. We will discuss each of these contributions in detail below.

Experience economy, in its initial article (Pine \& Gilmore, 1998), was discussed as a new era of consumption, replacing the age of functional benefits with experiences derived through consumption. Research from various disciplines realized the potential of this new paradigm and applied it in various settings. Through a review of literature, we identified numerous studies that applied the concept of experience economy in related contexts (e.g. Hosany \& Witham, 2009; Jung et al., 2016). This review identified some inconsistencies, such as different conceptualizations, inconsistent findings, and strong correlations between the four factors. Supplementing these observations with technology and media research and incorporating basic human decision making led to a novel conceptualization: The results support our theory that the elements of experience economy - esthetics, education, entertainment, and escapism - are not 'on the same level'. In contrast, our findings suggest that AR experiences start with an assessment of the esthetics. The assessment of the esthetics determines the magnitude of the remaining elements, namely education, entertainment, and escapism. This is an important contribution for several reasons. For example, as shown in Table 1, most prior experience economy studies concluded that only selected variables matter. In this study, we show that all four experience economy constructs are relevant within the AR context. However, the effect of esthetics is indirect, as mediated by education, entertainment, and escapism. Prior research that modelled these factors on the same conceptual level did not find these effects and, in addition, might have struggled with methodological issues such as multicollinearity. Thus, by drawing on prior research on decision making in related context, this study extends the understanding of experience economy specifically in the context of $\mathrm{AR}$, and likely also in other domains.

The second major contribution is grounded in the evaluation of the experience itself. While prior research has typically relied on satisfaction or behavioral intentions, this study provides a more nuanced assessment. In particular, we incorporated satisfaction and memory as direct consequences of the experience and as mediators in the experience-behavior relationships. Only few studies (e.g. Oh et al., 2007) have looked at the connection of experience economy to satisfaction and memory, however, without the dependent variable of visitor engagement. Considering the importance of engaging visitors in order to create memorable experiences, this is an important dimension that has not been explored within previous experience economy studies. Thus, this can be considered the main contribution to knowledge. Whilst all the experience economy constructs showed at least weak effects on both constructs, we identified a series of differences. For example, education showed the strongest effect, which is probably due to visitors' expectations to learn something. This indicates that visitors who are actively engaged in science festival activities gained new skills and knowledge (Oh et al., 2007). On the contrary, escapism showed the weakest effect, which may be due to the fact that current AR application contains more 
passive delivery of content (e.g. video clips of scientists). This implies that creation of interactive AR contents for active participation of visitors as well as immersive experience are critical for

\subsection{Practical Implications}

Many practical implications were identified from this study. First, esthetics is an important experience economy construct for AR experiences during science festivals, which clearly shows the importance of interface within AR applications for festival managers and application developers alike. Second, education, entertainment, and escapism experiences via AR have a positive impact on satisfaction and memory. Consequently, AR experiences will bring more memorable and satisfied visitor experience during science festivals. Therefore, festival organizers and applications developers should design more informative, enjoyable, and immersive AR experiences for science festival attendees. Third, science festival attendees will engage more when they have AR-enhanced experiences that tell the hidden stories of science and scientists attached to physical buildings, statues, and plaques. It is proven that AR experiences with place attachment is an effective way of encouraging visitor engagement with science festivals. Finally, AR is a useful tool to improve memory, which is particularly important for science festival attendees' engagement; thus, AR applications should contain visually attractive and interesting hidden stories for memorable experiences, which will have a higher impact on the success of science festivals. Overall, the present study focused on science festivals however, findings are important for managers from various disciplines that are involved in creating immersive, enjoyable and educational experiences through immersive technologies. Manthiou et al. (2014) for instance suggested that the four realms should act as guidelines as to how festivals should be organised and where priorities need to be placed. From this, our findings suggest that the design of applications acts as a stepping stone for creating entertaining, educational and immersive experiences that ultimately lead to the engagement of audiences. Therefore, previous examples from museums, schools and art galleries have shown the benefits of AR and our findings support the strength of this new and innovative technology in order to create memorable and satisfying experiences and support engagement. In fact, within the museum context, Lee et al. (2015) supported that the initial impression of an application with regards to its esthetical features leads to hedonic motivations and positive intentions to use the application in the future. The present study supports this finding and emphasises on application design. In order to do so, app developers are advised to follow the principles of the experience economy to ensure that content and functionalities result in the desired outcome. A study on AR requirements within the tourism context supported the importance of the four realms as tom Dieck et al. (2016) found that learning, hedonic features, comfort and application quality are key requirements for AR applications. In addition, a recent study from a festival found that the escaping from reality is one of the key advantages of using virtual applications (Jung et al., 2017). Consequently, the four realms of the experience economy are extremely important within the tourism context and science festival organisers are advised to incorporate these characteristics into festival activities to ensure visitor engagement.

\subsection{Limitations and Future Research}

As with every study, there are several limitations that need to be addressed. The first limitation relates to the data collection in only one city using one AR application, as it limits generalisation. Therefore, more research should be conducted on AR science festival experiences in different destinations. In addition, the present study was limited to the four realms of the experience 
economy, and further factors affecting visitors' satisfaction and memory of AR experiences and intention to engage with science should be explored and tested. Therefore, a mixed-method study should help to fully explore and validate determinants of visitor engagement. This is expected to enhance the explanatory power and extend existing theories. Finally, as discussed in Table 1, most prior research (and this study) has studied net-effects of the four experience economy constructs. During the last years, scholars (e.g., Woodside, 2016; Kourouthanassis et al., 2017; Pappas et al;., 2017; Woodside et al., 2015) have taken a different approach and studies suggest configuration analyses as a potential alternative to the standard regression-based net effects models (e.g. regression or SEM). The four constructs of experience economy could be combined with other factors (e.g., personality, culture and so forth) to identify complex and asymmetric relations between these constructs to explain desired outcomes ${ }^{1}$. This might lead to higher explanatory power and deeper insights into the mechanisms that drive consumer reaction in AR. In addition, the present study focused on visitor engagement from the tourists' point-of-view, and further research could explore the differences between domestic and international tourists with regards to which factors influence the engagement with science. For destination marketing organizations, this would provide important implications for AR application design and acceptance among diverse types of users.

\section{References}

Ali, F., Hussain, K., \& Ragavan, N. A. (2014). Memorable customer experience: examining the effects of customers experience on memories and loyalty in Malaysian resort hotels. Procedia-Social and Behavioral Sciences, 144, 273-279.

Ali, F., Ryu, K., \& Hussain, K. (2016). Influence of experiences on memories, satisfaction and behavioral intentions: A study of creative tourism. Journal of Travel \& Tourism Marketing, 33(1), 85-100.

Altimira, D., Clarke, J., Lee, G., Billinghurst, M., \& Bartneck, C. (2017). Enhancing player engagement through game balancing in digitally augmented physical games. International Journal of Human-Computer Studies, 103, 35-47.

Benny, L. K. W. (2015). Entertainment Studies-A Perspective. American International Journal of Research in Humanities, Arts and Social Sciences, 7-11.

Bultitude, K. (2014). Science festivals: do they succeed in reaching beyond the'already engaged'?. Journal of Science Communication, 13(4), 1-3.

Conway, M. A., Rubin, D. C., Spinnler, H., \& Wagenaar, A. (2013). Phenomenal Experience in Laboratory and Autobiographical Memory. Theoretical Perspectives on Autobiographical Memory, 65, 31-51.

Criado, N., \& Such, J. M. (2011, October). Preparing students for group assessment. In Next Generation Web Services Practices (NWeSP), 2011 7th International Conference on (pp. 421-426). IEEE.

Das Gupta, A., Karmarkar, U. S., \& Roels, G. (2015). The design of experiential services with acclimation and memory decay: Optimal sequence and duration. Management Science, 62(5), 1278-1296.

Fornell, C., \& Larcker, D. F. (1981). Structural equation models with unobservable variables and measurement error: Algebra and statistics. Journal of marketing research, 382-388.

\footnotetext{
${ }^{1}$ We thank a reviewer for this suggestion!
} 
602

603

604

605

606

607

608

609

610

611

612

613

614

615

616

617

618

619

620

621

622

623

624

625

626

627

628

629

630

631

632

633

634

635

636

637

638

639

640

641

642

643

644

645

646

647

Georgiou, Y., \& Kyza, E. A. (2017). The development and validation of the ARI questionnaire: An instrument for measuring immersion in location-based augmented reality settings. International Journal of Human-Computer Studies, 98, 24-37.

Hair, J. F., Black, W.C., Babin, B.J., Anderson, R.E., \& Tathman, R. L. (2006). Multivariate Data Analysis, 6th ed., Prentice Hall.

Han, D. I., Jung, T., \& Gibson, A. (2014). Dublin AR: Implementing augmented reality in tourism. In Z. Xiang, \& I. Tussyadiah (Eds.), Information and communication technologies in tourism (pp. 511-523). Vienna: Springer.

Hosany, S., \& Witham, M. (2009). Dimensions of cruisers' experiences, satisfaction, and intention to recommend. Journal of Travel Research, 49(3), 351-364.

Isiaq, O., \& Jamil, M. G. (2017). Exploring student engagement in programming sessions using a simulator. Paper presented at ICICTE, July, Crete.

Jensen, E., \& Buckley, N. (2014). Why people attend science festivals: Interests, motivations and self-reported benefits of public engagement with research. Public Understanding of Science, 23(5), 557-573.

Jung, T., Chung, N., \& Leue, M.C. (2015). The determinants of recommendations to use augmented reality technologies: The case of a Korean theme park. Tourism Management, 49, 75-86.

Jung, T., \& tom Dieck, M. C. (2017). Augmented reality, virtual reality and 3D printing for the co-creation of value for the visitor experience at cultural heritage places. Journal of Place Management and Development. 10 (2).

Jung, T., tom Dieck, M. C., Lee, H., \& Chung, N. (2016). Effects of Virtual Reality and Augmented Reality on Visitor Experiences in Museum. In Information and Communication Technologies in Tourism 2016 (pp. 621-635). Springer International Publishing.

Jung, T., tom Dieck, M.C., Moorhouse, N., \& tom Dieck, D. (2017). Tourists' experience of Virtual Reality applications. Paper presented at ICCE, January, Las Vegas.

Jung, T., Lee, H., Chung, N., and tom Dieck, M. C. (2018). Cross-Cultural Differences in Adopting Mobile Augmented Reality at Cultural Heritage Tourism Sites, International Journal of Contemporary Hospitality Management, 30(8).

Kahneman, D. (2011). Thinking, fast and slow. Macmillan, London.

Kalantari, M., \& Rauschnabel P.A. (2017). Exploring the Early Adopters of Augmented Reality Smart Glasses: The Case of Microsoft HoloLens. In Jung, T. and tom Dieck, M.C. (Eds). Augmented Reality and Virtual Reality - Empowering Human, Place and Business (pp. 229245), Springer, Cham.

Kang, M. \& Gretzel, U. (2012). Effects of podcast tours on tourist experience in a national park. Tourism Management, 22(2), 440-455.

Knutson, B. J., Beck, J. A., Kim, S., \& Cha, J. (2010). Service quality as a component of the hospitality experience: Proposal of a conceptual model and framework for research. Journal of Foodservice Business Research, 13(1), 15-23.

Kourouthanassis, P. E., Mikalef, P., Pappas, I. O., \& Kostagiolas, P. (2017). Explaining travellers' online information satisfaction: A complexity theory approach on information needs, barriers, sources and personal characteristics. Information \& Management, 54(6), 814-824.

Lee, H., Chung, N., and Jung, T. (2015). Examining the Cultural Differences in Acceptance of Mobile Augmented Reality: Comparison of South Korea and Ireland, In Tussyadiah, I. and Inversini, A. (Eds). Information and Communication Technologies in Tourism (pp. 477491). Springer Computer Science, Vienna. 
Loureiro, S. M. C. (2014). The role of the rural tourism experience economy in place attachment and behavioral intentions. International Journal of Hospitality Management, 40, 1-9.

Manthiou, A., Lee, S., Tang, L., \& Chiang, L. (2014). The experience economy approach to festival marketing: Vivid memory and attendee loyalty. Journal of Services Marketing, 28(1), 22-35.

Mehmetoglu, M., \& Engen, M. (2011). Pine and Gilmore's concept of experience economy and its dimensions: An empirical examination in tourism. Journal of Quality Assurance in Hospitality \& Tourism, 12(4), 237-255.

Molz, J.G. (2012). Travel Connections: Tourism, technology, and togetherness in a mobile world. Routledge: London.

Moorhouse, N., tom Dieck, M.C., \& Jung, T. (2017). Augmented Reality to enhance the Learning Experience in Cultural Heritage Tourism: An Experiential Learning Cycle Perspective, eReview of Tourism Research, 8, 1-5.

Morrison, A.M. (2013). Marketing and managing tourism destinations. Routledge: London.

Muthén, L. K., \& Muthén, B. O. (2013). Mplus: Statistical analysis with latent variables (Version 7.11) [Software]. Los Angeles: Muthén \& Muthén.

Mykletun, R., \& Rumba, M. (2014). Athletes' experiences, enjoyment, satisfaction, and memories from the Extreme Sport Week in Voss, Norway. Sport, Business and Management: An International Journal, 4(4), 317-335.

Neuburger, L., \& Egger, R. (2017). An Afternoon at the Museum: Through the Lens of Augmented Reality. In Schegg, R. \& Stangl, B. (Eds.). Information and Communication Technologies in Tourism 2017 (pp. 241-254). Springer, Heidelberg.

Neuhofer, B. Buhalis, D. \& Ladkin, A. (2015). Smart technologies for personalized experiences: a case study in the hospitality domain. Electron Markets, 243-254.

Neuhofer, B., Buhalis, D., \& Ladkin, A. (2012). Conceptualising technology enhanced destination experiences. Journal of Destination Marketing \& Management, 1, 36-46.

Oh, H., Fiore, A.M. \& Jeoung, M. (2007). Measuring experience economy concepts: Tourism applications. Journal of Travel Research, 46(2), 119-132.

Pallud, J., \& Straub, D. W. (2014). Effective website design for experience-influenced environments: The case of high culture museums. Information \& Management, 51(3), 359373.

Palmer, A. (2010). Customer experience management: a critical review of an emerging idea. Journal of Services marketing, 24(3), 196-208.

Pappas, I. O., Kourouthanassis, P. E., Giannakos, M. N., \& Lekakos, G. (2017). The interplay of online shopping motivations and experiential factors on personalized e-commerce: A complexity theory approach. Telematics and Informatics, 34(5), 730-742.

Park, M., Oh, H., \& Park, J. (2010). Measuring the experience economy of film festival participants. International Journal of Tourism Sciences, 10(2), 35-54.

Pine, B. J., \& Gilmore, J. H. (1998). The experience economy. Harvard Business Review, 76(6). 97-105.

Prayag, G., Hosany, S., Muskat, B., \& Del Chiappa, G. (2017). Understanding the Relationships between Tourists' Emotional Experiences, Perceived Overall Image, Satisfaction, and Intention to Recommend. Journal of Travel Research, 56(1), 41-54.

Quan, S., \& Wang, N. (2004). Towards a structural model of the tourist experience: An illustration from food experiences in tourism. Tourism Management, 25(3), 297-305. 
Quadri-Felitti, D., \& Fiore, A.M. (2013). Destination loyalty: Effects of wine tourists' experiences, memories, and satisfaction on intentions. Tourism and Hospitality Research, 1-16.

Ragin, C. C. (2008). Redesigning social inquiry: Fuzzy sets and beyond (Vol. 240). Chicago: University of Chicago Press.

Rauschnabel, P. A., \& Ro, Y. K. (2016). Augmented reality smart glasses: An investigation of technology acceptance drivers. International Journal of Technology Marketing, 11(2), $123-$ 148.

Rauschnabel, P. A., Rossmann, A., \& tom Dieck, M. C. (2017). An Adoption Framework for Mobile Augmented Reality Games: The Case of Pokémon Go. Computer in Human Behavior, 76, 276-278.

Shenton, A. K. (2004). Strategies for ensuring trustworthiness in qualitative research projects. Education for information, 22(2), 63-75.

Song, H. J., Lee, C. K., Park, J. A., Hwang, Y. H., \& Reisinger, Y. (2015). The influence of tourist experience on perceived value and satisfaction with temple stays: The experience economy theory. Journal of Travel \& Tourism Marketing, 32(4), 401-415.

Sørensen, F., \& Jensen, J. F. (2015). Value creation and knowledge development in tourism experience encounters. Tourism Management, 46, 336-346.

Stilgoe, J., Lock, S. J., \& Wilsdon, J. (2014). Why should we promote public engagement with science?. Public Understanding of Science, 23(1), 4-15.

Srivastava, M., \& Kaul, D. (2014). Social interaction, convenience and customer satisfaction: The mediating effect of customer experience. Journal of Retailing and Consumer Services, 21(6), 1028-1037.

Taheri, B., Jafari, A., \& O'Gorman, K. (2014). Keeping your audience: Presenting a Visitor Engagement Scale, Tourism Management, 42, 321-329.

tom Dieck, M.C. \& Jung, T. (2018). A theoretical model of mobile augmented reality acceptance in urban heritage tourism. Current Issues in Tourism, 21(2), 154-174

tom Dieck, M. C., Jung, T. H., Kim, W. G., Kim, W. G., \& Moon, Y. (2017). Hotel guests' social media acceptance in luxury hotels. International Journal of Contemporary Hospitality Management, 29(1), 530-550.

tom Dieck, M. C., Jung, T. H., \& tom Dieck, D. (2016). Enhancing art gallery visitors' learning experience using wearable augmented reality: generic learning outcomes perspective. Current Issues in Tourism, 1-21.

Tscheu, F., \& Buhalis, D. (2016) Augmented reality at cultural heritage sites. In Inversini, A., \& Schegg, R., (2016). Information and Communication Technologies 2016 (pp. 607-619). Springer, Heidelberg.

Tussyadiah, I., Jung, T., \& tom Dieck, M.C. (2017). Embodiment of Wearable Augmented Reality Technology in Tourism Experiences, Journal of Travel Research, In Press.

Valle, P. O. D., Silva, J. A., Mendes, J., \& Guerreiro, M. (2006). Tourist satisfaction and destination loyalty intention: a structural and categorical analysis. International Journal of Business Science and Applied Management, 1(1), 25-44.

Wixom, B., \& Todd, P. (2005). A theoretical integration of user satisfaction and technology acceptance. Information Systems Research, 16(1), 85-102.

Woodside, A. G. (2016). Embrace Complexity Theory, Perform Contrarian Case Analysis, and Model Multiple Realities. In Bad to Good: Achieving High Quality and Impact in Your Research (pp. 57-81). Emerald Group Publishing Limited. 
738 Woodside, A. G., Prentice, C., \& Larsen, A. (2015). Revisiting problem gamblers' harsh gaze on 739 casino services: Applying complexity theory to identify exceptional customers. Psychology \& Marketing, 32(1), 65-77.

741 Wu, H.K. Lee, S.W.Y. Chang, H.Y., \& Liang, J.C. (2013). Current status, opportunities and

742

743 challenges of augmented reality in education. Computers and Education, 41-49. 


\section{Appendix}

745

\section{Constructs and definitions}

747

\begin{tabular}{ll}
\hline Constructs & Definition \\
\hline Esthetics & "The beauty that can be expressed though the elements such as color, photographs, font style, \\
& and layout" (Lee et al., 2015, p. 481) \\
Education & The absorption of "events unfolding before [a tourist] at a destination, while actively \\
& participating through interactive engagement of the mind" (Oh et al., 2007, p. 121) \\
Entertainment & Entertainment is "an activity that provides amusement and pleasure" (Benny, 2015, $p .7)$ \\
Escapism & The escape "of [tourists] regular environments to suspend the power of norms and values that \\
& govern their ordinary lives or to think about their lives and societies from a different \\
Memories & The "mental revival of conscious experience" (Conway et al., 2013, p. 31) \\
Satisfaction & The "psychological state experienced by the consumer when confirmed or disconfirmed \\
& expectations exist with respect to a specific service transaction or experience" (Palmer, 2010, \\
Visitor & Visitor engagement is " a state of being involved with and committed to a specific market \\
engagement & offering" (Taheri et al., 2014, p. 322)
\end{tabular}




\begin{tabular}{lcccc} 
Dependent Variable: Memory & $95 \% \mathrm{CI}_{\mathrm{low}}$ & $\beta$ & $95 \% \mathrm{CI}_{\text {high }}$ & Mediation? \\
\hline Total Indirect (sum) & $\mathbf{0 . 4 9 1}$ & $\mathbf{0 . 6 4 0}$ & $\mathbf{0 . 7 9 5}$ & $\checkmark$ \\
\hline Estethics - Education - Memory & 0.163 & 0.304 & 0.469 & $\checkmark$ \\
Estethics - Entertainment - Memory & 0.048 & 0.180 & 0.329 & $\checkmark$ \\
Estethics - Escapist - Memory & 0.060 & 0.156 & 0.259 & $\checkmark$
\end{tabular}

\begin{tabular}{lcccc} 
Dependent Variable: Satisfaction & $95 \% \mathrm{CI}_{\text {low }}$ & $\beta$ & $95 \% \mathrm{CI}_{\text {high }}$ & Mediation? \\
\hline Total Indirect (sum) & $\mathbf{0 . 3 3 5}$ & $\mathbf{0 . 4 7 0}$ & $\mathbf{0 . 6 1 7}$ & $\checkmark$ \\
\hline Estethics - Education - Satisfaction & 0.143 & 0.237 & 0.363 & $\checkmark$ \\
Estethics - Entertainment - Satisfaction & 0.094 & 0.188 & 0.295 & $\checkmark$ \\
Estethics - Escapist - Satisfaction & -0.004 & 0.045 & 0.098 & $\times$ \\
\hline
\end{tabular}

752 Note: coefficients are unstandardized effects. ML estimator and bootstrapping (10,000 resamples) applied. 